\title{
African Development Bank
}

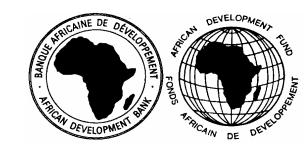

\section{Economic Research Working Paper Series}

\section{Agricultural Trade Policy Reform in South Africa}

\author{
Margaret Chitiga \\ Associate Professor, Economics Department, \\ University of Pretoria \\ Tonia Kandiero \\ Senior Research Economist, the Chief Economist Complex \\ African Development Bank \\ and \\ Phindile Ngwenya \\ Deputy Director, Economic Policy Division \\ National Treasury

\section{Economic Research Working Paper No 95 (March 2008)}

The views and interpretations in this paper are those of the author(s) and do not necessarily represent those of the African Development Bank. 
Copyright@ 2008

African Development Bank

\author{
African Development Bank \\ Angle des trois rues: Avenue du Ghana, Rue Pierre de Coubertin, Rue Hédi Nouira \\ BP. 323 \\ 1002 Tunis Belvedere \\ Tunisia \\ TEL: (+216) 71103487 \\ FAX: (+216) 71103779 \\ E-MAIL: afdb@afdb.org
}

\title{
Rights and Permissions
}

All rights reserved.

The text and data in this publication may be reproduced as long as the source is cited. Reproductions for commercial purposes are forbidden.

The African Development Bank disseminates the findings of work in progress to encourage the exchange of ideas about economic research and policy issues in Africa. Our main objective is to disseminate findings quickly, so we compromise and bear with presentations that are not fully polished. The papers are signed by the author(s) and should be cited and referred accordingly. The findings, interpretations, and conclusions expressed in this paper are entirely those of the author(s). They do not necessarily represent the view of the African Development Bank, its Board of Directors, or the countries they represent.

Working Papers are available online at http://www.afdb.org/ 


\title{
Agricultural Trade Policy Reform in South Africa
}

\author{
Margaret Chitiga* \\ Tonia Kandiero** \\ and \\ Phindile Ngwenya
}

\begin{abstract}
This paper empirically investigates the impact of agricultural trade reform in South Africa. Using UNCTAD's Agricultural Trade Policy Simulation Model (ATPSM), the study performs two specific scenarios that capture the magnitude of (i) the economic impact of global agricultural trade reform in South Africa and (ii) the economic impact if the reform in South Africa is coupled with agricultural reforms in the European Union (EU). Trade reform focuses on substantial tariffs reduction, although in the case of the EU scenarios also include reduction in domestic support and export subsidies. The results show that unilateral tariff reduction in the selected number of agricultural products amounts to welfare gains of US\$21 million. These gains are three times higher when accompanied by extensive reforms in the EU.
\end{abstract}

\footnotetext{
* Margaret Chitiga is an Associate Professor, Economics Department, University of Pretoria, Pretoria, South Africa: E-mail: Margaret.chitiga@up.ac.za Acknowledgments.

* Tonia Kandiero is a Senior Research Economist in the Chief Economist Complex, Department, African Development Bank, Temporary Relocation Agency, P.B. 323 Tunis, Tunisia: E-mail: tkandiero@afdb.org.

** Phindile Ngwenya is a Deputy Director, Economic Policy, National Treasury, Pretoria, South Africa: : E-mail: Phindile.ngwenya@treasury.gov.za

Comments are welcome; please send any communication directly to the authors.
} 


\section{Introduction}

The importance of the agricultural sector in South Africa cannot be stressed enough. In 2006, the agriculture sector contributed about 2.8 percent of Gross Domestic Product (GDP), 8.5 percent of total employment and approximately 4 percent of total exports (Statistics South Africa, 2007; Department of Trade and Industry (dti), 2007). The agricultural sector has three sub-sectors: agriculture, forestry and fishing. The agriculture sub-sector comprises field crops, horticulture and livestock farming. The performance of field crops has a pivotal role in the determination of food security and overall performance of the sector. This activity was responsible for 25.5 percent of the gross value of production in the agriculture sector in 2006 (Department of Agriculture, 2007). The most important field crops grown in South Africa are maize, sugar, sunflower and wheat. South Africa is a net exporter of maize and sugar and a net importer of wheat. In 2006, exports of sugar and its products (sucrose, lactose, glucose, fructose, molasses and confectionery) constituted 19 percent of total agricultural exports $(d t i, 2007)$. Horticulture also played an important role as it accounted for 24.7 percent of agricultural sector production in 2006 (Department of Agriculture, 2007). In South Africa, horticulture consists of fruit (deciduous, citrus and subtropical), vegetables and flowers. Most horticultural exports are sent to the European Union (EU).

The performance in the agricultural sector is also affected by South Africa's participation in different trade agreements. South Africa is a signatory to a number of trade agreements which contributed to the liberalisation of the agricultural sector. Participation in global trade agreements reduced distortions which existed from indirect export subsidies such as electricity and transport rebates, export finance and credit guarantees and marketing allowances (Kirsten et al, 2004). In addition, South Africa undertook several labour policy reforms. The combination of liberalisation and stricter labour laws exposed the agricultural sector to the adverse effects of globalisation. 
In South Africa, the objective of trade policy in the agricultural sector is to promote the integration of this sector into the world economy in order to encourage greater access to markets, technology, capital as well as competition (OECD 2006). All these activities have a direct or indirect impact on economic growth.

The principal idea of this study, therefore, is to empirically investigate the impact of global agricultural trade reforms in South Africa. In addition, the study investigates the magnitude of benefits if the EU also liberalises unilaterally. The merit of this type of reform process is that it treats all trade partners equally, which in turn reduces any possibility of trade diversion. Furthermore, it gives government what is known as "commitment technology". This, in turn, provides a positive signal for investors to make long-term commitments. Lastly, unilateral reform can then be used to make concessions in trade negotiations on multilateral, bilateral and regional levels.

The policy relevance of this study is to investigate if global agricultural trade liberalisation is economically beneficial. In other words, should South Africa continue to liberalise? The study investigates two specific scenarios that capture the magnitude of (i) the economic impact of global agricultural trade reform in South Africa and (ii) the economic impact if the reform in South Africa is coupled with reforms in the EU. In this study, reform will focus on substantial reduction in tariffs, domestic support and export subsidies.

The EU was selected as a case study because it is South Africa's main trading partner and one of the regions whose agricultural policies create distortions in the world market. Although the bilateral trade agreement is not the focus of this investigation, it is important to note that in October 1999 South Africa signed a bilateral Trade, Development and Co-operation Agreement (TDCA) with the EU. Full implementation began in May 2004, where the parties agreed to liberalise over periods of up to 10 years in the EU and 12 years in South Africa. Under the TDCA, a free trade area would be established by the end of 2012 and would cover 90 percent of total trade between the parties. Liberalisation included South Africa removing duties on 81 percent of its agricultural imports from the EU while the EU would remove duties, including partial liberalisation of quotas, on 61 percent of its agricultural imports from South Africa. This liberalisation agenda does not include "sensitive 
products", which include bananas, sugar, beef, rice, maize, sweetcorn, starches, fruits and vegetables to the EU. The sensitive list for South Africa includes fresh meats, dairy products, some cereals and sugar products. The most important development in the EU relations is that South Africa is now part of the Economic Partnership Agreements Negotiations between the EU and the Southern Africa Development Community (SADC). This is part of the agenda to strengthen regional integration in the SADC and to move towards a single set of trade agreements with the EU.

This study parallels the simulations presented in the OECD (2006). The report reviews agricultural trade policies in South Africa using a Global General Equilibrium Trade Model, GTAPEM, a modified version of Global Trade Analysis Project (GTAP). The simulations focus on multilateral policy scenarios and cover all the sectors. The contribution of this study is the focus on unilateral trade reform in South Africa and the EU. This study utilises a partial equilibrium framework to investigate the welfare impact of trade reform. The strength of the model is that it is specifically designed for agricultural trade simulations. Therefore, it covers more products and countries than the general equilibrium model.

The paper is divided into six sections. Following the introduction, section two provides an overview of tariffs, domestic support and export subsidies in South Africa and in the EU. The methodology used for the empirical investigation is presented in section three. Results are discussed in section four. Section five offers policy recommendations and section six concludes the study.

\section{Border Protection and Support in South Africa and the EU}

\subsection{Applied Tariffs}

What are the welfare implications of imposing tariffs? The benefits of imposing tariffs are government revenue and protection of domestic industries. The cost imposed by tariffs includes increased domestic prices, thus reducing consumer welfare. The ripple effect is that the higher prices affect suppliers as farmers respond by increasing output. This impacts on consumers through demand patterns. 
Trade policy in the agricultural sector was accelerated when South Africa became a signatory to the Uruguay Round Agreement on Agriculture (URAA), leading to the Marketing of Agricultural Products Act (1996). This Act went further than the WTO agreements and reduced state intervention in agricultural marketing and product prices. The objective was to provide free access for all market participants, thus promoting efficiency of agricultural products, improving opportunities for export earnings and enhancing the viability of the sector. During the implementation of the Act, South Africa made large strides in terms of removing export subsidies and substantially reducing domestic support. However, high tariffs and the structure of support in areas such as sugar, among other products, need to be revisited. South Africa should be aware that fundamental unilateral trade reforms are necessary if policies in agriculture are to meet the changing demands of consumers, at the same time avoiding any negative impacts on producers and international trade.

Ad valorem tariffs apply to agro-food products and tariff quotas (of 20 percent) as well as to agricultural products under the minimum market access commitments. For agricultural and food products, protection takes the form of specific and ad valorem tariffs, tariff rate quotas, and anti-dumping and countervailing duties. Export permits are required if products need to comply with certain EU or US quota arrangements so as to ensure equitable access by small and medium enterprises. Although the average tariff level in South Africa has been reduced over the years, it remains complex and dispersed. Therefore protection is uneven and gains from openness could be hampered.

Table 1 presents 34 major agricultural commodities in the Agricultural Trade Policy Simulation Model (ATPSM) by the UNCTAD. Details of the model will be discussed in section five. In South Africa, bovine meat, milk, sheep meat, butter, cheese, sugar, cigarettes and other manufactured tobacco products have applied tariff rates of over 15 percent (tariffs over 15 percent are considered tariff peaks). The minimum applied tariff is zero and the maximum tariff is 105 percent (see Table 1 and Table 2). In the EU, 62 percent of the products are above 15 percent, while tariff peaks in South Africa are only 29 percent. In the EU products such as meat, dairy, sugar and cereal have applied tariff levels over 50 percent, with milk reaching a maximum tariff in excess of 113 percent. However, the EU tariffs are more dispersed than in the case of 
South Africa (see Figure 1). This can be explained by the large standard deviation in the EU applied rates and the dispersion in the density function (see Table 2). Tariff dispersion reflects tariff escalation, as in the case of cocoa and sugar. ${ }^{1}$

A wide variety of tariffs applied to the same commodities across countries distorts trade and lowers efficiency and responsiveness on world markets (Josling, 2006). According to Hoekman, $\mathrm{Ng}$ and Olarreaga (2001), tariff peaks and tariff escalation have a disproportional impact on exports in Africa and other developing countries. Therefore, with regard to tariff peak items, complete duty-free access for Africa and other developing countries in the EU and other markets in developed countries would result in 11 percent (US\$2.5 billion) increase in their total exports. It is important to note that applied tariff rates in the EU are the same as the bound rates in the WTO, while in the case of South Africa most of the bound rates are higher than applied rates. The amount of "water" in the tariffs gives South Africa some room to increase applied rates without violating WTO commitments. The preliminary observation at this point is that protection is in the products that the EU and South Africa consider as "sensitive products".

1 Tariff escalation: When importing countries escalate their tariffs in this way, they make it more difficult for countries producing raw materials to process and manufacture value added products for export. 
Table 1: Applied tariffs for a selected number of agricultural products in South Africa* and the EU

\begin{tabular}{|c|c|c|c|c|}
\hline \multirow[b]{2}{*}{ Commodities } & \multicolumn{2}{|c|}{ South Africa } & \multicolumn{2}{|l|}{ EU } \\
\hline & Applied Initial & Bound Initial & Applied Initial & Bound \\
\hline Livestock & 0 & 0 & 52 & 52 \\
\hline Bovine meat & 30 & 99 & 87 & 87 \\
\hline Sheep meat & 32 & 81 & 64 & 64 \\
\hline Pig meat & 19 & 37 & 20 & 20 \\
\hline Poultry & 14 & 58 & 37 & 37 \\
\hline Milk, conc. & 96 & 96 & 113 & 113 \\
\hline Butter & 79 & 79 & 112 & 112 \\
\hline Cheese & 95 & 95 & 46 & 46 \\
\hline Wheat & 13 & 47 & 54 & 54 \\
\hline Rice & 0 & 0 & 72 & 72 \\
\hline Barley & 1 & 12 & 34 & 34 \\
\hline Maize & 3 & 50 & 26 & 26 \\
\hline Sorghum & 2 & 35 & 33 & 33 \\
\hline Pulses & 10 & 27 & 2 & 2 \\
\hline Tomatoes & 20 & 37 & 23 & 23 \\
\hline Roots \& tubers & 0 & 0 & 21 & 21 \\
\hline Apples & 3 & 4 & 30 & 30 \\
\hline Citrus fruits & 4 & 4 & 26 & 26 \\
\hline Bananas & 5 & 37 & 11 & 11 \\
\hline Other tropical fruits & 16 & 24 & 19 & 19 \\
\hline Sugar, raw & 17 & 26 & 55 & 55 \\
\hline Sugar, refined & 105 & 105 & 82 & 82 \\
\hline Coffee, green & 0 & 119 & 4 & 4 \\
\hline Coffee, proc. & 23 & 119 & 11 & 11 \\
\hline Cocoa beans & 0 & 0 & 0 & 0 \\
\hline Cocoa, proc. & 0 & 0 & 20 & 20 \\
\hline Tea & 4 & 170 & 7 & 7 \\
\hline Tobacco leaves & 10 & 10 & 8 & 8 \\
\hline Hides \& skins & 0 & 0 & 0 & 0 \\
\hline Oilseeds, temp. & 8 & 44 & 0 & 0 \\
\hline Oilseeds, trop. & 7 & 30 & 0 & 0 \\
\hline Rubber & 0 & 10 & 0 & 0 \\
\hline Cotton & 5 & 56 & 0 & 0 \\
\hline Vegetable oils & 8 & 72 & 7 & 7 \\
\hline Average & 18 & 47 & 32 & 32 \\
\hline
\end{tabular}

*Note: Uses tariffs for 2004, which may not reflect recent changes Source: ATPSM (2005) 
Figure 1: Applied tariff rates in South Africa and the EU

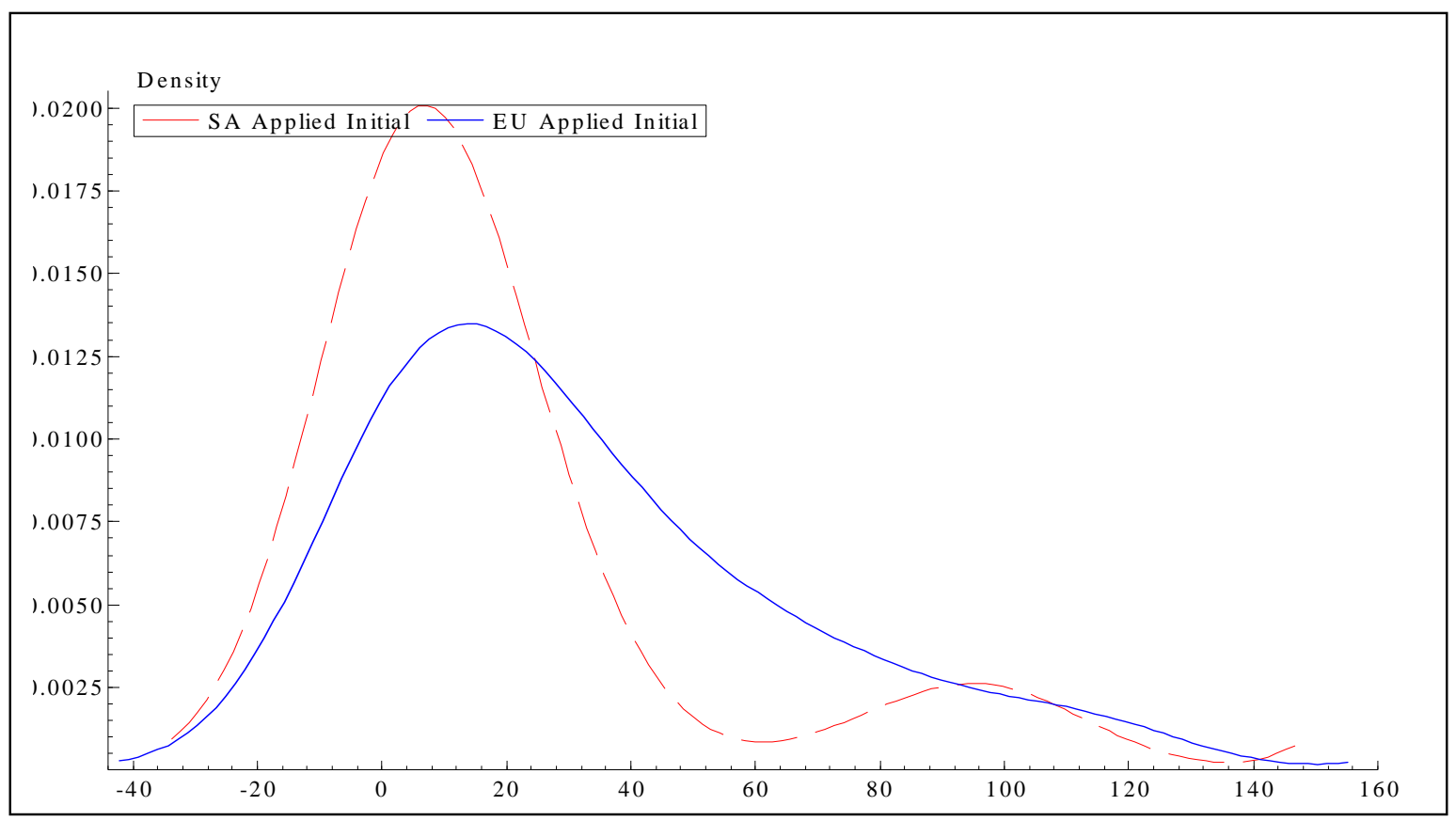

$\mathrm{X}$-axis - tariffs (percent); Y-axis - Probability (tariffs)

Table 2: Summary statistics of tariff rates

\begin{tabular}{|l|c|c|}
\hline Statistics & $\begin{array}{c}\text { South Africa } \\
\text { (Percent) }\end{array}$ & $\begin{array}{c}\text { EU } \\
\text { (Percent) }\end{array}$ \\
\hline Mean & 18 & 32 \\
\hline Standard Deviation & 29 & 32 \\
\hline Minimum & 0 & 0 \\
\hline Maximum & 105 & 113 \\
\hline Peaks (tariffs $>15$ percent) (No. of lines) & 10 & 21 \\
\hline Number of observations & 34 & 34 \\
\hline
\end{tabular}

Note: Descriptive statistics of average tariff rates

\subsection{Measures of Support to Agriculture}

One of the measures of support to agriculture is Producer Support Estimate (PSE). ${ }^{2}$ PSEs capture the overall effects of different types of governmental programs and interventions in a single number. This method is better compared to other tools like nominal or effective rates of protection, since these often account for only a small

\footnotetext{
${ }^{2}$ This measure of support to agriculture is used by the OECD to monitor support in the Member countries.
} 
proportion of the transfers between the government and the producers of agricultural commodities.

PSEs can be represented in different ways. There are two in particular, which are appropriate and suitable for cross-country comparisons. In the first measure, the PSE can be expressed as a proportion of transfers to producers, multiplied by 100 to get the Percentage PSE. It presents the PSEs relative to the size of the farmers' gross revenue. The other is PSE per Unit of Output of a commodity where the PSE is divided by the level of production. This measure captures the subsidies provided by the government for the production of a unit of output. For simplicity purposes, Percentage PSEs (\% PSE) are considered rather than PSE per Unit of Output.

$\%$ PSE can be expressed as:

$$
\begin{aligned}
\% \text { PSE } & =\frac{\text { Total transfers }}{\text { Value to producers }} \\
& =\frac{\left(Q \times\left(P_{d}-P_{w} \times X\right)+G+I\right)}{\left(Q \times P_{d}+G\right)}
\end{aligned}
$$

Where: $\mathrm{Q}=$ the quantity produced

$$
\begin{aligned}
& P_{d}=\text { the producer price in domestic currency units. } \\
& P_{W}=\text { the world price in world currency units. } \\
& X=\text { an exchange conversion factor } \\
& G=\text { direct government payments } \\
& I=\text { Indirect transfers }
\end{aligned}
$$

Equation (1) means that \% PSE could be negative if the domestic price is less than the world reference price or positive if domestic price is greater than world reference price. In addition, the level of \%PSE is determined by the level of distortion created by increased price support. Trade distorting support contributes to lower world prices and inflicts a cost on producers in countries not protecting their domestic markets. Furthermore, even if government policies remain unchanged, changes in exchange 
rates and domestic production can alter \% PSE. Also, not all transfers have the same weight in the \%PSE measurement. In calculating \%PSE, transfers from price support programs and direct payments $(\mathrm{G})$ appear in both the numerator and the denominator. However, indirect transfers (I) appear only in the numerator. The implication is that a country's \% PSE can decline or increase without changing total transfers to producers merely by shifting transfers from indirect programs to direct payments or price support programs.

\subsubsection{Support to Agriculture in South Africa and the EU}

South Africa introduced incentive programmes during the 70's and these incentives continued into the 80's. These incentives boosted exports but came at a cost to the fiscus (Kirsten, et al, 2004; Cassim and Onyango, 2003). Most of the support to farmers declined substantially during the implementation of the 1994 URAA, as explained by the decline in the levels of support after 1997 (see Table 3). No export subsidy applies for agro-food products, even though the pricing regime for sugar effectively subsidises sugar exports, while the costs are carried by the domestic consumer.

Table 3: Support to agriculture (PSE) in US\$ million

\begin{tabular}{|c|c|c|c|c|c|c|c|c|c|c|c|}
\hline & 1994 & 1995 & 1996 & 1997 & 1998 & 1999 & 2000 & 2001 & 2002 & 2003 & 2004 \\
\hline South Africa & 871 & 1,539 & 989 & 1,068 & 631 & 671 & 372 & 140 & 569 & 487 & \\
\hline EU & 90,180 & 96,779 & 93,199 & 95,318 & 100,917 & 107,173 & 93,338 & 93,061 & 96,989 & 104,474 & 107,686 \\
\hline OECD & 273,570 & 267,257 & 254,561 & 234,373 & 253,583 & 272,852 & 242,971 & 219,500 & 226,451 & 256,752 & 279,527 \\
\hline
\end{tabular}

Source: OECD (2006)

In South Africa, about 96 percent of the remaining support is in the form of Market Price Support (MPS) and a small portion is given to farmers based on input use and farm income. ${ }^{3}$ MPS maintains domestic prices for farm goods at different levels from those at the country's border. Tariffs, quotas and other restrictions on imports as well

\footnotetext{
${ }^{3}$ Market price support for a product $=($ administered price at the farm gate - fixed external reference price) $\mathrm{x}$ eligible production. Market price support for an input (service) $=($ administered price at the farm gate - market price) x quantity of input (service) receiving subsidy
} 
as subsidies on exports, together with government intervention to boost domestic prices through, for example, stock-building, create a gap between domestic market prices and world prices for commodities at the border. Multiplying that price gap by the amount of domestic production gives the MPS to producers in the PSE. At the same time that domestic producers receive higher prices for commodities, consumers also have to pay those higher prices. In other words, Market Price Support channels transfers from consumers to farmers.

In terms of products, support is mainly in raw sugar, wheat, maize, milk, meat and fruit, with sugar having the highest MPS of R1, 259 million in 2003. Table 1 in the Appendix shows Nominal Protection Coefficients (\%NPC) for South Africa and the EU. The coefficients in all the products are higher than 1, meaning that domestic prices are higher than world prices. In South Africa, the NPC for raw sugar was the highest in 2003, amounting to 1.46. In other words, the domestic price was 46 percent higher than the world price. This means that, at present, sugar is subsidised and the product may not have the competitive advantage in the world market.

South Africa's support to agriculture is very small compared with the EU. The EU group of countries uses most of the domestic support and export subsidies. Support to agriculture in the EU is one of the contentious issues in current multilateral negotiations. The impasse in the Doha Round is attributed to a lack of commitment by the EU, the US and other major players to reduce support to agriculture. Support in the EU accounts for about 40 percent of total OECD support (see Figure 2). Hoekman and Olarreaga (2006) argue that developing countries' agricultural exports of about US\$70 billion face US\$90 billion worth of support in developing countries (excluding green box support) and agricultural exports of US\$20 billion face US\$8 billion in export subsidies in developed countries.

Most of the support in the EU is also in the form of MPS and is found in sensitive products like dairy, cereal, meat products, sugar and some fruit. \% PSE in the EU was seven times more than in South Africa in 2003. The \% PSE in the EU has remained around 30 percent since 1994. In the case of South Africa, the numbers are lower and more volatile as a result of the volatility of the exchange rate. 
Figure 2: Support to agriculture in South Africa, EU and OECD

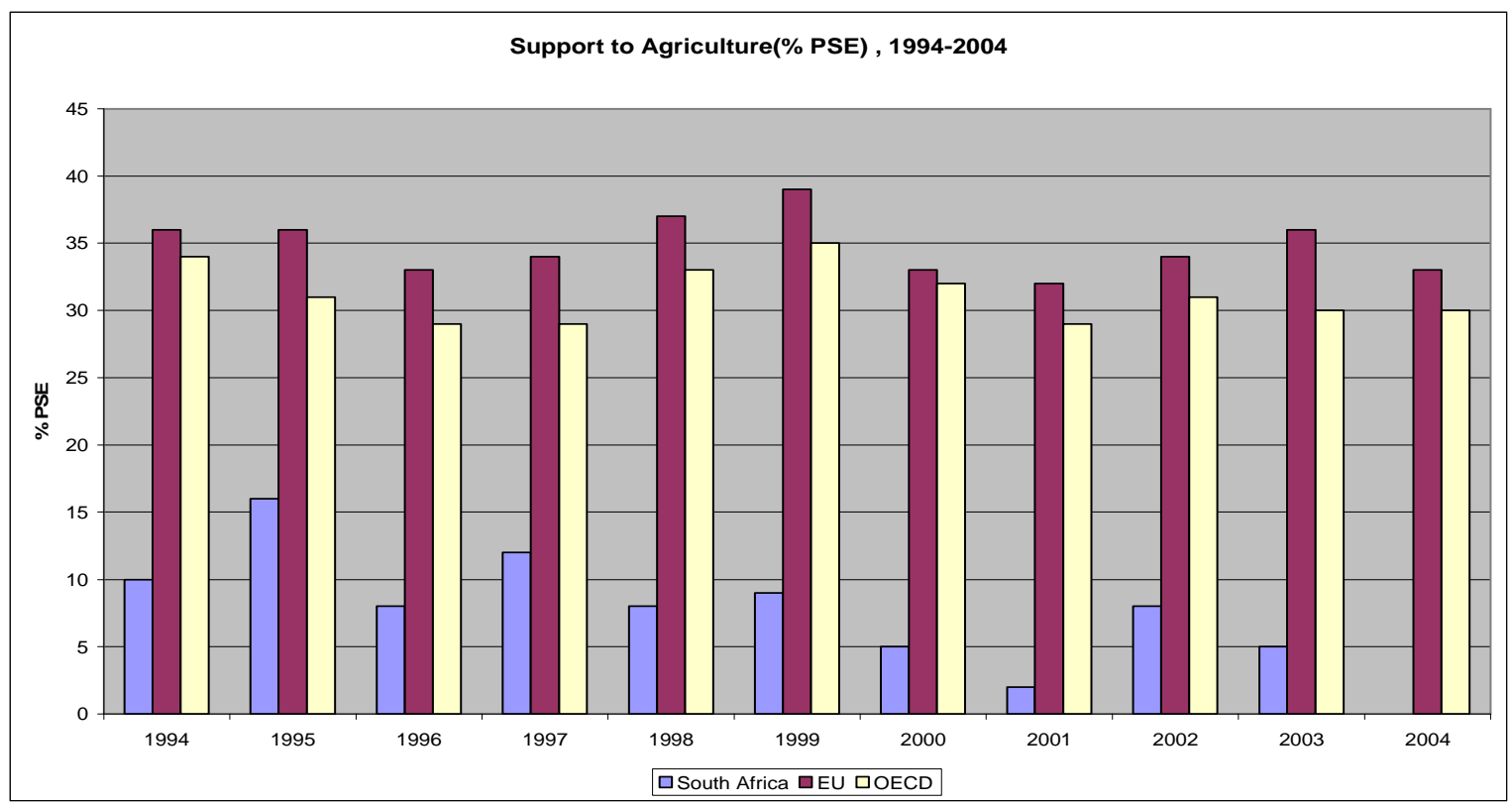

Source: OECD (2005)

It is important to note that MPS requires trade policy in order to operate and to sustain the domestic price of a commodity above the international prices. As a result, high tariffs are in place for a number of products that receive support. This is seen in the particular case of sugar.

\section{ATPSM Methodology}

The analysis utilises UNCTAD's Agricultural Trade Policy Simulation Model (ATPSM). The ATPSM model attempts to simulate real world situations. The ATPSM, developed jointly by UNCTAD and the Food and Agriculture Organization (FAO), is a global trade model designed primarily for simulating agricultural trade policies, notably in the context of the URAA on Agriculture.

One of the strengths of this model is that it allows a detailed specification of the most relevant agricultural trade policies to have computable economic effects. In addition, ATPSM is able to report results for many different countries. The model gives results not only globally but also for various country groups and geographical locations. There is an extensive coverage of agricultural commodities and the model considers 
the inter-relationships between the agricultural commodities in both supply and demand (for example, when competing for land or consumer preferences). Lastly, the model accounts for three different economic agents within each economy - producers, consumers and government. In this regard, results can be presented by commodity and by agent for each country, each region or the world.

ATPSM can simulate the effects of a range of trade policy instruments, notably: reduction of out-of-quota (or MFN) tariffs, either by a certain percentage, or with the tariff harmonizing Swiss formula; reduction of in-quota tariffs; expansion of tariff rate quotas volumes; reduction of domestic subsidies; and reduction of export subsidies.

\section{ATSM characteristics}

The ATPSM is a comparative-static, synthetic, multi-commodity, multi-region, partial-equilibrium world trade model for agricultural products. It also accounts for the distribution of quota rents, solutions for equilibrium world market prices and their impact on domestic production and trade flows. It explicitly covers 161 countries (160 individual countries and the EU's 15 countries, treated as one country). The model is also fairly comprehensive in its commodity coverage with a total of 36 agricultural commodities.

All policy instruments are defined in ad valorem equivalent terms. Therefore, specific tariffs are converted to ad valorem rates and both domestic and export subsidies are similarly expressed in their respective ad valorem equivalents.

Production or domestic supply-and-demand depends linearly on domestic prices. Imports clear the market. The world prices are linked to domestic prices by price transmission equations. The price transmissions are assumed to be complete. Both demand and supply specifications account for cross-effects. The demand function for country $r$ and commodity $i$ are expressed as:

$$
D_{i, r}^{\prime}=\beta_{i, j, r}+\left[P_{w t}^{\prime}+\left(1+t_{c i, r}^{\prime}\right)\right]+\sum_{\substack{j=1 \\ j \neq 1}}^{J} \beta_{i, j, r}\left[P_{w j}^{\prime}+\left(1+t_{c j, r}^{\prime}\right)\right]
$$

Domestic supply for country $r$ and commodity $i$ are similarly expressed as 


$$
S_{i, r}^{\prime}=\alpha_{i, j, r}\left[P^{\prime}{ }_{w t}+\left(1+t_{p i, r}^{\prime}\right)\right]+\sum_{\substack{j=1 \\ j \neq 1}}^{J} \alpha_{i, j, r}\left[P_{w j}^{\prime}+\left(1+t_{p j, r}^{\prime}\right)\right]
$$

The import and export functions are expressed as

$$
\begin{gathered}
\Delta M_{i, r}=D_{i, r} D_{i, r}^{\prime}-S_{i, r} S_{i, r}^{\prime}+\Delta X_{i, r} \\
\Delta X_{i, r}=\psi_{i, r} \Delta S_{i, r}
\end{gathered}
$$

Where: $D, S, X$, and $M$ denote demand, supply, exports and imports, respectively; a letter followed by ' represents relative change. $P_{w}$ denotes world price, $t_{c}$ denotes the domestic consumption tariff and $t_{p}$ denotes the domestic production tariff, $\alpha$ denotes supply elasticity, $\beta$ denotes demand elasticity, $\psi$ the ratio of exports to production, $i, j$ are commodities indexes and $r$ is a country index. These four equations are applied to each country.

The export equation implies that the change in export in each market is some proportion of the change in production. This proportion is determined by the ratio of exports to production. For example, if half of the initial production is exported, half of the change in production is also exported, which entails that the proportion of exports to production is maintained. Finally, imports clear the market, i.e., production plus imports equals domestic consumption plus exports. Domestic prices are determined as a function of the world market prices and policy variables, for example support measures, tariffs, subsidies and quotas.

Trade revenue and welfare effects are computed-based on volume responses (i.e., $\Delta \mathrm{X}$, $\Delta \mathrm{M}, \Delta \mathrm{S}$ and $\Delta \mathrm{P})$ and price changes. The trade revenue effect of a policy change is computed for each country and commodity as follows:

$$
\Delta R=\left(P_{W}+\Delta P_{W}\right)[(X+\Delta X)]-[(M+\Delta M)]-P_{W}(X-M)
$$

Total welfare is the sum of producer surplus, consumer surplus and government revenue, i.e. $\Delta \mathrm{W}=\Delta \mathrm{PS}+\Delta \mathrm{CS}+\Delta \mathrm{GR}$. Following a simulation, change in total 
welfare consists of the changes in these three components. ${ }^{4}$ The changes in producer and consumer surpluses depend on changes in domestic market prices and changes in production and consumption quantities. Change in net government revenue $(\Delta \mathrm{GR})$ includes a change in tariff revenue, a change in export subsidy expenditure, a change in domestic support expenditure and a change in quota rent not received by exporters. For each country and commodity, $\Delta \mathrm{GR}=\Delta \mathrm{TR}-\Delta \mathrm{ES}-\Delta \mathrm{DS}+(1-\mathrm{k}) \Delta \mathrm{U}$, where TR is tariff revenue, ES is export subsidy expenditure, DS is domestic support expenditure and (1-k) $\Delta \mathrm{U}$ is change in quota rent forgone. The capture rate, $\mathrm{k}$, is the proportion of the rent captured by exporting producers as opposed to the proportion, 1-k, going to the importing country.

The model generates outputs in terms of both changes in quantities and percentage changes from the base period for the following variables:

- Quantities- exports, imports, production and consumption (X, M, S and D);

- Trade values - export, import and net trade balance;

- Welfare effects - producer surplus, consumer surplus, government revenue and total welfare

- Prices - world market prices (and consumer) and farm prices.

\section{Data sources}

The model is based on data from various sources. The quantities of production, consumption, exports and imports (in metric tonnes) are from FAOSTAT (Supply and Utilization Accounts and Trade Domain data). All prices are expressed in US dollars and are assembled from various sources. The base period for the model is 1998-2000 for production, imports, exports, etc. while tariffs and other policy parameters are based on the final year of implementation of the URAA (2000 for developed and 2004 for developing countries). In-quota tariffs, out-of-quota tariffs and global quotas are from the $\mathrm{AMAD}^{5}$ database and were aggregated to the ATPSM commodity levels.

\footnotetext{
${ }^{4}$ A change in net government revenue is measured as in-quota and out-of-quota tariff revenue less export subsidy and domestic support expenditures and quota-rent foregone.

${ }^{5}$ AMAD: Agricultural Market Access Data Base, http://www.amad.org/files/index.htm
} 
UNCTAD COMTRADE ${ }^{6}$ is the main source for bilateral trade flows, while applied tariffs are from the TRAINS ${ }^{7}$ database.

\section{Model limitations}

All commodities are assumed to be tradable, for example, there is no independent behaviour for domestic prices. There are no other domestic policies besides the Amber Box subsidies. All agricultural commodities are assumed to be homogeneous and so there is perfect substitution among goods produced in different countries, an assumption that may not always hold.

The model does not account for the possibility of countries exerting market power, although it is well known that the international trade of several agricultural products is often concentrated in a small number of companies. Being a comparative static model, not all non-price developments in supply and demand are captured. Finally, there is no income variable in the model.

An important assumption is that within-quota tariffs are not relevant even where quotas are unfilled. This means that the higher out-of-quota tariffs or applied rates (whichever is operative in a particular situation), are the key determinants of domestic prices. This assumption tends to overstate the benefits of liberalisation, as there may be cases where in-quota rates are the relevant determinants of domestic prices. ATPSM does not account for preferential access and trade diversion. Bilateral quotas are allocated by a complex procedure based on each country's import and export shares. Quota rents are distributed in proportion to trade flows.

In this context, the following assumptions are made. First, there are no stochastic shocks or other uncertainties. Second, the model is static which means that there is no specific time dimension to the implementation of policy measures or to the maturing of their economic effects. Finally, ATPSM is a partial equilibrium model. Although the model aims at estimating far-reaching details of the agricultural economy, it does

\footnotetext{
${ }^{6}$ COMTRADE: http://unstats.un.org/unsd/comtrade/

${ }^{7}$ TRAINS: http://r0.unctad.org/trains
} 
not deal with the repercussions of barrier reductions on other parts of the national economy. Therefore, effects on the industrial and service sectors of the economy or the labour market are not subject to analysis.

For the purpose of this exercise, ATPSM analyses the impact of trade policy changes on demand-and-supply using a system of simultaneous equations. The model compares two states at a similar point in time: one with the policy change and one without it. The model is used to estimate the potential impact of various proposals for reforming the agricultural trade sector, assuming their implementation is as specified. The global agricultural-trade model is able to estimate the economic effects of changes in in-quota, applied and out-of-quota tariffs, import quotas, export subsidies and domestic support on production, consumption, prices, trade flows, trade revenues, quota rents, producer surplus, consumer surplus and welfare. The data in the model is based on the 4 digit HS Code.

Details of this model are explained in Peters and Vanzetti (2004b) and applied in Peters and Vanzetti (2004a). The model was also used extensively by FAO and UNCTAD in their technical assistance activities within developing countries so as to assess the impact of bound tariff reduction proposals to the Doha Round.

\section{The Economic Impact Agricultural Policy Reform in South Africa and the EU}

\subsection{Results}

The study investigates two policy scenarios, presented in Table 4. In the first scenario, South Africa is assumed to liberalise unilaterally, for example, reducing tariffs by 50 percent while keeping the rest of the world unchanged. In the second scenario liberalisation in South Africa is combined with partial liberalisation in the EU, where the EU would reduce tariffs, domestic support and subsidies by 50 percent. Support in South Africa was reduced substantially during the Uruguay Round and through domestic reform processes. This means there is less pressure to propose further reduction in that area. 
Table 4: Policy options

\begin{tabular}{lll}
\hline Country & Policy & Scenario \\
\hline 1. South Africa & Tariff (out of quota) & $50 \%$ tariff reduction \\
& $\begin{array}{l}\text { Domestic support } \\
\text { Export subsidies }\end{array}$ \\
2. EU & Tariff (out of quota) & 50 per cent \\
& Domestic support & 50 per cent \\
& Export subsidies & 50 per cent \\
\hline
\end{tabular}

\section{Scenario 1: The Implication of Applied Tariff Reduction on Change in Total Welfare, Consumer Surplus (CS), Producer Surplus (PS), Total Revenue and Trade in South Africa (US\$ million)}

Table 5 shows that unilateral liberalisation in South Africa in a selected number of agricultural key products results in a total welfare gain of US\$21 million. As expected, most of the welfare gains are in highly protected products such as meat products, dairy and sugar.

McDonald, Punt and Leaver (2004) support the findings on sugar. They analyse the impact of trade liberalisation in the sugar industry in South Africa using a Computable General Equilibrium (CGE) analysis. Their results indicate that there would be substantial welfare gains across all household groups and that, overall, agricultural producers in South Africa should benefit. However, there are substantial variations in the impact upon agricultural producers in different provinces. Gauteng, Mpumalanga and the North West would experience negative effects from the reform process, while Kwa Zulu-Natal, Free State and the Northern Cape would benefit. The benefits are large enough to offset the negative impact. This result could also be an indication of lower agriculture activities in Gauteng and other two provinces. 
Table 5: Implications of Applied Tariff Reduction in South Africa alone on Consumer Surplus (CS), Producer Surplus (PS), Welfare, Total Revenue and

Trade in South Africa (US\$)

\begin{tabular}{|c|c|c|c|c|c|c|c|}
\hline Commodities & Change in TW & Change in CS & Change in PS & Change in GR & Change in XR & Change in MC & Change in TB \\
\hline Livestock & $-9,440$ & 36,627 & $-46,066$ & 0 & $-870,436$ & $7,628,182$ & $-8,498,618$ \\
\hline Bovine meat & $2,634,481$ & $4,220,841$ & 300 & $-1,586,660$ & 3,580 & $-915,529$ & 919,109 \\
\hline Sheep meat & $2,481,222$ & $21,119,785$ & $-18,023,889$ & $-614,674$ & $-311,197$ & $13,197,872$ & $-13,509,070$ \\
\hline Pig meat & 134,032 & $2,560,088$ & $-668,607$ & $-1,757,449$ & $-185,202$ & $1,065,460$ & $-1,250,662$ \\
\hline Poultry & $4,159,689$ & $51,501,999$ & $-43,626,227$ & $-3,716,082$ & $-775,384$ & $44,116,759$ & $-44,892,143$ \\
\hline Milk, conc. & 952,889 & $8,380,366$ & $-3,070,566$ & $-4,356,912$ & $-277,618$ & $1,733,444$ & $-2,011,062$ \\
\hline Butter & $1,114,834$ & $5,050,576$ & $-2,579,710$ & $-1,356,032$ & $-175,488$ & $2,053,131$ & $-2,228,619$ \\
\hline Cheese & $3,590,798$ & $12,680,639$ & $-8,172,386$ & $-917,455$ & $-871,712$ & $6,336,067$ & $-7,207,779$ \\
\hline Wheat & 635,084 & $13,792,837$ & $-10,968,988$ & $-2,188,766$ & $-359,299$ & $7,115,914$ & $-7,475,213$ \\
\hline Rice & 3,859 & 4,248 & -388 & 0 & $1,678,366$ & $-188,043$ & $1,866,410$ \\
\hline Barley & $-1,806$ & 99,228 & $-33,536$ & $-67,498$ & 54,283 & $-350,534$ & 404,817 \\
\hline Maize & $-11,772$ & 500,238 & $-351,200$ & $-160,810$ & 112,995 & $-580,235$ & 693,230 \\
\hline Sorghum & -575 & 2,093 & $-1,902$ & -766 & 204,552 & $-38,297$ & 242,849 \\
\hline Pulses & 96,456 & $2,546,120$ & $-1,809,875$ & $-639,789$ & $-68,687$ & $1,355,681$ & $-1,424,368$ \\
\hline Tomatoes & 565,050 & $4,326,740$ & $-3,282,637$ & $-479,052$ & $-810,851$ & $5,187,845$ & $-5,998,695$ \\
\hline Roots \& tubers & 0 & 0 & 0 & 0 & 0 & 0 & 0 \\
\hline Apples & 659 & 31,161 & $-12,858$ & $-17,644$ & $-4,002$ & 29,510 & $-33,512$ \\
\hline Citrus fruits & 3,185 & 154,285 & $-48,840$ & $-102,260$ & $-45,857$ & 115,070 & $-160,927$ \\
\hline Bananas & 9,754 & 289,397 & $-257,837$ & $-21,806$ & $-11,926$ & 367,217 & $-379,143$ \\
\hline Other tropical fruits & 90,859 & 898,967 & $-553,227$ & $-254,882$ & $-97,780$ & $1,089,379$ & $-1,187,159$ \\
\hline Sugar, raw & $4,105,451$ & $34,787,741$ & $-33,714,099$ & $3,031,809$ & $-18,494$ & $37,493,741$ & $-37,512,235$ \\
\hline Sugar, refined & $-432,707$ & 733,652 & $-732,242$ & $-434,116$ & $26,449,125$ & $-210,255$ & $26,659,380$ \\
\hline Coffee, green & 746 & 912 & -166 & 0 & $-1,251$ & -848 & -402 \\
\hline Coffee, proc. & 29,214 & $1,333,199$ & $-325,013$ & $-978,973$ & $-38,888$ & 191,616 & $-230,504$ \\
\hline Cocoa beans & 0 & 0 & 0 & 0 & 0 & 0 & 0 \\
\hline Cocoa, proc. & 0 & 0 & 0 & 0 & 0 & 0 & 0 \\
\hline Tea & 14,443 & $1,542,383$ & 3,413 & $-1,531,354$ & 3,890 & 476,779 & $-472,888$ \\
\hline Tobacco leaves & 160,732 & $4,919,072$ & $-1,916,497$ & $-2,841,842$ & $-158,511$ & $2,381,574$ & $-2,540,084$ \\
\hline Hides \& skins & 6,234 & -991 & 7,224 & 0 & 513,006 & 991 & 512,016 \\
\hline Oilseeds, temp. & 268,690 & $6,105,119$ & $-5,894,319$ & 57,889 & $-11,553$ & $5,061,854$ & $-5,073,407$ \\
\hline Oilseeds, trop. & 58,024 & $1,865,550$ & $-1,120,162$ & $-687,364$ & $-80,132$ & $1,246,392$ & $-1,326,524$ \\
\hline Rubber & 0 & 0 & 0 & 0 & 0 & 0 & 0 \\
\hline Cotton & 9,216 & $1,260,104$ & $-116,961$ & $-1,133,927$ & $-43,362$ & 248,792 & $-292,154$ \\
\hline Vegetable oils & 203,102 & $6,229,022$ & $-2,365,575$ & $-3,660,345$ & $-68,661$ & $3,381,401$ & $-3,450,062$ \\
\hline Total & $20,872,402$ & $186,971,999$ & $-139,682,838$ & $-26,416,759$ & $23,733,507$ & $139,590,929$ & $-115,857,422$ \\
\hline
\end{tabular}

Notes: $\mathrm{TW}=$ total welfare; $\mathrm{CS}=$ consumer surplus; $\mathrm{PS}=$ producer surplus; $\mathrm{GR}=$ government revenue; $\mathrm{XR}=$ export revenue; $\mathrm{MC}=$ import cost $\mathrm{TB}=$ trade balance.

Source: Authors' Estimates

The increase in exports as a result of liberalisation in the 34 agricultural products amounts to US\$24 million, which represent a 4 percent growth in exports. Most of the gains come from sugar exports. As a result of improved market access conditions due to tariff reduction, imports increase by US\$140 million. About 69 percent of the increase in imports is observable in poultry, sheep meat and sugar. The trade balance, however, declines as imports outpace exports. After the simulation, the trade deficit 
worsened by US\$115 million. Given the high current account in recent years, perhaps the impact should not be ignored. Overall, consumers in South Africa gain the most as domestic prices decline due to the trade policy reform process. This result is compelling in the context that most low income households in South Africa spend a substantial portion of their income on food, especially meat products. Therefore, the liberalisation process in agriculture is likely to be a positive contribution to poverty reduction through positive welfare gains.

The loss in government revenue amounts to US\$26 million, with major revenue loss occurring in milk, poultry, vegetable oils and sugar. The implication would be a reduction in the revenue to Botswana, Namibia, Lesotho and Swaziland (BLNS). However, on the whole, total welfare improves as a result of a US\$187 million gain in consumer surplus. This is seen in lower domestic prices due to the decline in tariffs, although the gains are offset by a loss of US\$ 139 million in producer surplus.

\section{Scenario 2: Implications of Applied Tariff Reductions in South Africa and the EU on Consumer Surplus (CS), Producer Surplus (PS), Welfare, Total Revenue and Trade in South Africa (US\$ million)}

In the second scenario, the trade liberalisation in South Africa is combined with

reforms in the EU. In the case of South Africa, the reform process is only restricted to market access since export subsidies were abolished during the implementation of the Uruguay Round and the unilateral reforms that followed and the levels of domestic support are considered minimal. Table 6 presents the results of the second scenario. 


\section{Table 6: Implications of Applied Tariff Reductions in South Africa and the EU on Consumer Surplus (CS), Producer Surplus (PS), Welfare, Total Revenue and Trade in South Africa (US\$ million)}

\begin{tabular}{|c|c|c|c|c|c|c|c|}
\hline Commodities & Change in TW & Change in PS & hange in CS & hange in GR & lange in XR & Change in MC & Change in TB \\
\hline Livestock & $-776,832$ & $-3,802,438$ & $3,025,606$ & 0 & $-1,502,567$ & $7,130,773$ & $-8,633,340$ \\
\hline Bovine meat & $2,626,051$ & 427,541 & $3,654,825$ & $-1,456,315$ & $1,462,406$ & $-32,221$ & $1,494,626$ \\
\hline Sheep meat & $1,440,751$ & $-15,918,000$ & $19,065,038$ & $-1,706,287$ & 409,721 & $6,375,454$ & $-5,965,734$ \\
\hline Pig meat & $2,148,073$ & $3,068,177$ & 862,668 & $-1,782,773$ & $2,423,069$ & 796,648 & $1,626,420$ \\
\hline Poultry & $1,782,282$ & $-29,830,619$ & $36,213,486$ & $-4,600,585$ & 106,541 & $31,232,607$ & $-31,126,066$ \\
\hline Milk, conc. & $6,668,046$ & $10,936,120$ & 843,052 & $-5,111,127$ & $9,409,582$ & 164,503 & $9,245,079$ \\
\hline Butter & 497,348 & $-1,080,428$ & $3,066,005$ & $-1,488,229$ & 300,715 & $1,718,560$ & $-1,417,846$ \\
\hline Cheese & $2,368,888$ & $-4,012,426$ & $8,382,593$ & $-2,001,278$ & 506,987 & $4,054,443$ & $-3,547,457$ \\
\hline Wheat & $-1,035,932$ & $2,246,038$ & $-692,983$ & $-2,588,987$ & 994,436 & $1,132,545$ & $-138,109$ \\
\hline Rice & $-690,708$ & 69,594 & $-760,302$ & 0 & $-1,048,366$ & 851,155 & $-1,899,520$ \\
\hline Barley & $-585,531$ & 525,274 & $-1,050,953$ & $-59,852$ & 29,709 & $1,164,331$ & $-1,134,622$ \\
\hline Maize & $3,588,653$ & $12,123,248$ & $-8,300,683$ & $-233,912$ & $4,630,948$ & $-2,419,113$ & $7,050,061$ \\
\hline Sorghum & 55,942 & 216,245 & $-161,015$ & 712 & 32,890 & 109,472 & $-76,582$ \\
\hline Pulses & 88,331 & $-1,768,061$ & $2,497,656$ & $-641,263$ & $-62,952$ & $1,337,185$ & $-1,400,137$ \\
\hline Tomatoes & 673,949 & $-24,072$ & $1,625,995$ & $-927,975$ & 684,048 & 884,678 & $-200,630$ \\
\hline Roots \& tubers & 67,659 & 91,022 & $-16,986$ & $-6,377$ & 112,059 & 8,422 & 103,637 \\
\hline Apples & $5,903,172$ & $10,138,894$ & $-4,199,452$ & $-36,271$ & $14,155,070$ & $-1,089,209$ & $15,244,280$ \\
\hline Citrus fruits & $4,924,616$ & $7,448,957$ & $-2,322,832$ & $-201,508$ & $12,162,163$ & $-4,819,390$ & $16,981,553$ \\
\hline Bananas & 54,511 & 522,439 & $-422,001$ & $-45,928$ & 100,858 & $-597,660$ & 698,518 \\
\hline Other tropical fruits & 304,898 & 223,974 & 395,352 & $-314,428$ & 329,478 & 349,219 & $-19,741$ \\
\hline Sugar, raw & $2,683,046$ & $-24,744,112$ & $25,353,713$ & $2,073,445$ & $-3,808$ & $25,996,260$ & $-26,000,069$ \\
\hline Sugar, refined & $11,445,264$ & $46,338,793$ & $-34,014,480$ & $-879,049$ & $81,610,057$ & $-210,255$ & $81,820,312$ \\
\hline Coffee, green & 80,253 & $-17,908$ & 98,161 & 1 & $-18,732$ & $-91,304$ & 72,572 \\
\hline Coffee, proc. & 56,763 & $-248,987$ & $1,283,595$ & $-977,845$ & 21,764 & 201,287 & $-179,523$ \\
\hline Cocoa beans & 2,402 & -136 & 2,538 & 0 & -58 & $-1,346$ & 1,287 \\
\hline Cocoa, proc. & 154,559 & 568,879 & $-381,823$ & $-32,497$ & 804,894 & 126,359 & 678,535 \\
\hline Tea & 16,763 & 9,247 & $1,538,827$ & $-1,531,312$ & 10,539 & 479,159 & $-468,620$ \\
\hline Tobacco leaves & 44,194 & $-155,8247$ & $4,446,031$ & $-2,843,590$ & $-1,693$ & $2,347,422$ & $-2,349,115$ \\
\hline Hides \& skins & $17,064,459$ & $19,669,727$ & $-2,605,268$ & 0 & $30,343,187$ & $2,605,186$ & $27,738,001$ \\
\hline Oilseeds, temp. & 189,736 & $-4,660,627$ & $4,836,451$ & 13,913 & 767 & $3,967,905$ & $-3,967,138$ \\
\hline Oilseeds, trop. & 57,783 & $-1,114,176$ & $1,858,649$ & $-686,690$ & $-71,024$ & $1,266,094$ & $-1,337,118$ \\
\hline Rubber & 0 & 0 & 0 & 0 & 0 & 0 & 0 \\
\hline Cotton & 9,216 & $-116,961$ & $1,260,104$ & $-1,133,927$ & $-43,362$ & 248,792 & $-292,154$ \\
\hline Vegetable oils & $-229,709$ & $-1,885,531$ & $5,317,754$ & $-3,661,932$ & 46,735 & $3,342,977$ & $-3,296,242$ \\
\hline Total & $61,678,898$ & $23,841,440$ & $70,699,322$ & $-32,861,863$ & $157,936,058$ & $88,630,938$ & $69,305,121$ \\
\hline
\end{tabular}

Notes: $\mathrm{TW}=$ total welfare; $\mathrm{CS}=$ consumer surplus; $\mathrm{PS}=$ producer surplus; $\mathrm{GR}=$ government revenue; $\mathrm{XR}=$ export revenue; $\mathrm{MC}=$ import cost $\mathrm{TB}=$ trade balance.

Source: Authors Estimates

The removal of distortions in the EU improves total welfare gains by US\$62 million.

This is about three times more than the previous scenario, with over 80 percent of the gains coming from meat, dairy, fruits, sugar, cereal and surprisingly hides and skins (considered sensitive products in the EU and South Africa). The loss in government revenue of US\$32 million emanates mainly from dairy and vegetable oils. The boost 
in total welfare is from consumer surplus of US\$71 million, with meat and sugar as the main beneficiaries. On the trade side, exports increase by US $\$ 158$ million, representing an increase of 77 percent. Approximately half of the gains are from refined sugar as a result of the comprehensive reform in the EU.

Here it is important to note that the EU only allows imports of raw sugar, which it then refines and exports. According to the EU commitments to the WTO, the region's subsidised export of sugar is approximately 5 million tonnes every year. This excess sugar volume depresses the international market price, while EU producers can sell at a guaranteed high price. The reduction of such distortions is reflected by these gains.

Other products that also gain in terms of exports include apples, citrus fruit, milk, hides and skins. Total imports of the selected agricultural products increase by US\$89 million, with poultry and sugar imports increasing the most. South African products that enjoy relatively high protection in the EU benefit from improved market access.

It is important to mention that maize and citrus fruit imports decline the most due to the opening up of the markets. Although not included in the table, domestic production of these two products increases substantially as a result of the reform process. This is mainly due to higher global prices as a result of the reform process, leading to more domestic production. The course-grain price increases on average about 0.4 percent. The overall change in the trade balance as a result of trade reform is positive. The improved market access conditions in the EU substantially boost agricultural export performance in South Africa. The increase is mainly due to an increase in sugar and fruit exports. OECD (2006) also concludes that the agricultural policy in the OECD countries is likely to bring benefits to South Africa. The gains would be more visible in products such as wheat, fruit and vegetables, dairy products, processed sugar and other processed foods.

We also look at the impact of the global trade policy reform on major agriculture producers in developing countries such as Brazil and India. The findings indicate that these two countries gain the most from the global reforms in the EU and South Africa, particularly in the sugar sector. In Brazil, exports of raw and refined sugar increase by 
US\$120 million and US\$273 million, respectively, while in India the change is US\$544 million and US\$131 million in the same products. The overall change in total exports for Brazil amounts to US\$1.2 billion and to US\$1.4 billion for India. Other export areas in which Brazil gains substantially include bovine meat (US\$183 million), poultry (US\$141 million) and citrus fruit (US\$217 million). India’s exports of wheat increase by US $\$ 245$ million.

\section{Tariff revenue considerations of the two scenarios}

Tariffs have two major purposes: as an instrument for industrial policy and an instrument for revenue collection. In the case of South Africa, the former is more important where the tariff structure in rationalised based on protecting specific industries to support specific national interests. For South Africa, revenue from international trade taxes is a very small portion of the overall fiscal revenue. According to the National Treasury (2007), the tariff revenue in 2006/2007 amounted to an estimated 5 percent of the total tax revenue on average (1 percent of GDP). This is a reduction from the 7 percent in 1990. Therefore, full liberalisation, which would entail zero revenue, would have minimal impact on the country's fiscal position. In fact, the loss in fiscal revenue would be offset by the reduction in transfers to BLNS countries.

For the BLNS countries that depend on tariff revenues, trade reform should not be viewed in a negative way. Intuitively, the BLNS countries-including South African consumers- will benefit from higher welfare as a result of lower prices. Furthermore, the reduction in tariffs may facilitate the import of food inputs which may be used in agro-processing, which in turn can boost exports. The high utilization of imported inputs in agro-processing or industrial goods is increasing globally although in South Africa and other African countries the pace has been slow. This global phenomenon is also known as "trade in tasks". In this respect, higher tariffs should not be maintained to protect specific industries at the expense of promoting exports, the very objective 
that countries are trying to achieve. ${ }^{8}$ Therefore, for the BLNS countries, the objective should be to adopt a gradual trade policy reform process in order to harness the opportunities and to manage costs associated with trade liberalisation, such as revenue loss. The revenue pool could be used as an instrument for adjustment and other instruments in the Aid for Trade agenda could also be utilised.

\section{Policy Recommendations}

The analysis has given some guidance in terms of aspects of the trade policy issues that South Africa should consider. The policy recommendations focus on market access issues, investment in agricultural sector, South Africa's involvement in trade negotiations and adjustment considerations.

Market Access in South Africa: South Africa liberalised from the 1990's until 2001, in particular in the area of domestic support and export subsidies. However, there is room for improvement in the area of market access. Dairy and meat products, for example, are some of the products that are highly protected. The analytical work shows that the reform process in this sector would result in large welfare gains, which increase when combined with reforms in the EU. The most important contribution of this scenario is that higher welfare gains as a result of lower prices have the potential to improve the welfare of low income households who spend most of their income on food.

External Trade Agreements: The idea of this exercise was to assess the impact of unilateral reforms. The outcomes can be used to aid bilateral and multilateral trade negotiations. In the case of the Trade and Development Co-operation Agreement (TDCA) with the EU, gains will largely depend on what products are included. Long lists of sensitive products, which are excluded from negotiations, are the products

\footnotetext{
${ }^{8}$ This discussion on revenue is a big topic in the EPAs negotiations. A forthcoming paper by Collier and Vernables (2007) calls revenue loss in resource rich and aid rich economies as "Illusory Revenues".
} 
from which South Africa could gain if protection levels were reduced. Benefits from liberalisation could be undermined if trade agreements have too much flexibility through "sensitive products" and "special product" categories. During the review of the TDCA, it is important that negotiators revisit the reserve list and consider including some of the products which have high protection in the liberalisation agenda. These include sugar, fruit, meat, dairy and some cereals. Under the WTO Trade Negotiations, South Africa should continue to push the EU and other developed countries into reducing trade distorting domestic support and export subsidies, in addition to market access in products of interest to South Africa. However, the modalities for reductions in support should remain conservative in the case of developing countries.

Adjustment Issues: Another critical issue to bear in mind is that good policy design requires the consideration of a wide range of economic, social and political factors that vary across and within countries. From a practical point of view, policy should take into consideration the fact that some dislocation and adjustment should be expected (i.e. in the case of raw sugar where the producer surplus declines substantially as a result of agricultural reforms in South Africa and in the EU). In many cases, farmers will adapt well to a more open market environment. Others may need temporary assistance, for example, to change their farming practices or scale of operation, or to diversify their income sources, if they are to remain within the sector. In other cases, transitional support so as to enable farmers to shift into more viable employment opportunities outside of agriculture may be needed, for example, through responsive labour market policies.

Future Research: This study did not tackle the issue of Sanitary and Phytosanitary Measures (SPS) and Technical Barriers to Trade (TBT). However, as tariffs continue to decline it is important that South Africa strengthens the capacity to deal with these issues and requirements in developed countries such as the EU. Otsuki et al. (2000) analysed the impact of EU aflatoxin standards on food exports from nine African countries and found that they decreased relevant exports by approximately 64 percent or US\$ 700 million. So far, developing countries have raised 67 SPS cases in the WTO and they have supported 73 cases. South Africa has not raised any cases but has 
supported three. There is a need for extensive research into the impact of standards in South Africa.

In the case of South Africa the scenarios did not apply any reductions in domestic support because the levels are already low relative to the EU (OECD, 2006). This calls for consideration for more support in agriculture in order to increase export performance in the sector. The type of interventions could be in areas such as policy and regulatory framework; research, advisory services and training; and private sector development, marketing and rural finance. Future research, therefore, could investigate the impact of some the interventions on export performance in the agriculture sector.

\section{Conclusions}

Along the lines of studies by Gorter, Ingco and Ruiz (2000) and Ingco (1995), this study also supports the notion that in the trade liberalisation process, "own" (domestic) reforms are important. In addition, given that there are major distortions in agricultural trade at the global level; further gains will be derived from a substantial reduction of existing export subsidies and reduction in other trade impediments by developed countries such as the EU. Our results show that unilateral tariff reduction in South Africa amounts to welfare gains of US\$21 million. These gains are three times higher when accompanied by extensive reforms in the EU. Although these gains are promising, tariff peaks still remain in areas such as meat and dairy, among others.

Market access is not the only important issue in boosting exports in agriculture. Beyond the scope of this study, the industry should also address supply-side bottlenecks associated with poor transport infrastructure, port logistics and infrastructure to meet health and technical standards. In addition, adjustment issues have to be taken into consideration in case some workers are displaced due to the liberalisation process. 


\section{References}

Cassim, R and D. Onyango (2003), 'State of Trade Policy in South Africa,' Trade and Industrial Policy Research (Tips) Report. (Tips: Pretoria).

Collier, P. and A. J. Venables (2007), Illusory Revenues: Tariffs in Resource-Rich and Aid-Rich Economies, paper supported by the Oxford Centre for the Analysis of Resource Rich Economies and the Centre for the Study of African Economies (Oxford University, United Kingdom).

Department of Agriculture (2007), Economic Review of the South African Agriculture, Pretoria.

Department of Trade and Industry (dti) (2007), Trade Statistics, http://www.thedti.gov.za/econdb/raportt/ rapmenu.html.

Department of Trade and Industry (2005), Gravity Model,' http://www.dti.gov.za/stats/gravity.pdf.

Gorter H., Ingco M., and Ruiz L. (2000), 'Export Subsidies and Domestic Support Measures: Issues and Suggestions for the New Multilateral Rules for the Next WTO Round,' (World Bank, Washington, DC).

Hoekman B., Ng F. and Olarreaga, M. (2006), 'The Impact of Agricultural Support Policies on Developing Countries.' In Reforming Agricultural Trade for Developing Countries, Volume 1, A. McCalla and J. Nash, eds: World Bank.

Hoekman B., Ng F. and Olarreaga, M. (2001). 'Tariff Peaks in the Quad and Least Developed Country Exports', Seminar presented at the World Bank, Washington DC.

Ingco M. (1995), Agricultural Trade Liberalization in the Uruguay Round: One Step Forward One Step Back?', Supplementary Paper for the Conference on Uruguay Round and Developing Countries. (World Bank, Washington, DC).

Josling, T (2006) 'Implication of Food Import Regulations and Market Access for Developing Countries,' In Reforming Agricultural Trade for Developing Countries, Volume 1, A. McCalla and J. Nash, eds: World Bank.

J. Kirsten, T. Kandiero, S. Ngqangweni, Y. Gebrehiwet (2004), 'The SADC Countries And The Uruguay Round Agreement On Agriculture A Review Of Progress And Challenges,' Technical Report Prepared for the World Bank.

Peters R. and Vanzetti D. (2004a), 'Shifting Sands: Searching for a Compromise in the WTO Negotiations on Agriculture,' (Geneva: UNCTAD).

Peters R. and Vanzetti D. (2004b), 'User Manual and Handbook on Agricultural Trade Policy Simulation Model' (ATPSM),'(Geneva: UNCTAD). 
Pursell G. and Gupta A. (1998), 'Trade Policies and Incentives in Indian Agriculture: Methodology, Background Statistics and Protection and Incentive Indicators, 196595', World Bank Mimeo. (World Bank, Washington, DC).

NDA (2007), Abstract of Agricultural Statistics: 2006, Department of Agriculture, Pretoria.

National Treasury (2007), Budget Review 2007, Pretoria.

OECD (2006), 'OECD Review of Agricultural Policies: South Africa,' OECD, Paris.

Otsuki, T., Wilson J. S., and Sewadeh M. (2000), 'Saving two in a billion: A case study to quantify the trade effect of European food safety standards on African Exports', Mimeo, World Bank.

McDonald, S, C. Punt and R. Leaver (2004), 'Trade Liberalisation, Efficiency and South Africa's Sugar Industry', Sheffield Economic Research Paper Series SERP.

Statistics South Africa (2007), Gross Domestic Product, Third Quarter: 2007, Pretoria.

UNCTAD (2003), 'Handbook on UNCTAD Agricultural Trade Policy Simulation Model (ATPSM C++ Version 2.2)', (Geneva: WTO). 


\section{Appendix}

\section{Nominal Protection (NP)}

Nominal protection is regarded as the simplest measure of protection. This measure of protection is a simple estimate of the extent to which the price of the particular product has been affected by government intervention. One of the notable flaws with this measure is that it does not control variations in input prices. Nominal protection is generally measured as the Nominal Protection Coefficient (NPC) of a product. This measure is defined as the ratio of the product's domestic price to its international price (Pursell and Gupta, 1998). In simple notations, NPC can be expressed as

$$
\mathrm{NPC}=\mathrm{P}_{\mathrm{d}} / \mathrm{P}_{\mathrm{r}}
$$

where $\mathrm{P}_{\mathrm{d}}$ is the domestic price of the commodity at the farm gate and

$P_{r}$ is the world reference price of what the producer would fetch under the free trade at the same exchange rate.

If NPC > 1 , then the product is protected.

If NPC $<1$, then the product is not protected or in effect taxed.

For large countries like the EU, the weighted averages of the state NPCs are calculated to represent the average for all EU's NPCs. The average NPC is expressed as

(2) $\quad \mathrm{NPC}_{\mathrm{w}}=\sum_{\mathrm{s}} \mathrm{NPC}_{\mathrm{s}} \psi_{\mathrm{s}}$

Where

(3) $\psi_{\mathrm{s}}=\mathrm{P}_{\mathrm{rs}} \mathrm{Q}_{\mathrm{s}} / \sum_{\mathrm{s}} \mathrm{P}_{\mathrm{rs}} \mathrm{Q}_{\mathrm{s}}$

(4) $\quad \sum_{\mathrm{s}} \psi_{\mathrm{s}}=1$

And $\mathrm{P}_{\mathrm{rs}}$ is the world reference price for the state, $\mathrm{Q}_{\mathrm{s}}$ is the crop production of the EU member,

$\mathrm{NPC}_{\mathrm{s}}$ is the nominal protection coefficient of the state for the crop,

$\mathrm{NPC}_{\mathrm{w}}$ is the weighted average nominal protection coefficient for the crop, and

$\mathrm{s}$ represents the members included in the average. 
Table 1: Support to Agriculture (\% NPC)

\begin{tabular}{|lccccccccccc|}
\hline & $\mathbf{1 9 9 4}$ & $\mathbf{1 9 9 5}$ & $\mathbf{1 9 9 6}$ & $\mathbf{1 9 9 7}$ & $\mathbf{1 9 9 8}$ & $\mathbf{1 9 9 9}$ & $\mathbf{2 0 0 0}$ & $\mathbf{2 0 0 1}$ & $\mathbf{2 0 0 2}$ & $\mathbf{2 0 0 3}$ & $\mathbf{2 0 0 4}$ \\
\hline South Africa & 1.10 & 1.12 & 1.08 & 1.13 & 1.09 & 1.10 & 1.05 & 1.01 & 1.10 & 1.04 & \\
EU & 1.43 & 1.38 & 1.30 & 1.32 & 1.41 & 1.48 & 1.32 & 1.27 & 1.31 & 1.34 & 1.29 \\
OECD & 1.42 & 1.34 & 1.29 & 1.29 & 1.36 & 1.42 & 1.35 & 1.28 & 1.30 & 1.29 & 1.28 \\
\hline
\end{tabular}

Source: OECD (2005)

Table 2: Implications of Applied Tariff Reductions and South Africa and in the EU on

Consumer Surplus (CS), Producer Surplus (PS), Welfare and Total Revenue and

Trade on Argentina and Brazil (US\$)

\begin{tabular}{|c|c|c|c|c|c|c|c|c|}
\hline \multirow[b]{2}{*}{ Products } & \multicolumn{3}{|c|}{ Brazil } & \multirow[b]{2}{*}{ Change in TB } & \multicolumn{3}{|c|}{ India } & \multirow[b]{2}{*}{$\begin{array}{l}\text { Change in } \\
\text { TB }\end{array}$} \\
\hline & Change in TW & Change in XR & Change in MC & & Change in TW & Change in XR & $\begin{array}{l}\text { Change in } \\
\text { MC }\end{array}$ & \\
\hline Livestock & $-55,374$ & $12,336,082$ & $-7,234,677$ & $19,570,759$ & $-5,033,965$ & -94 & $-17,146,404$ & $17,146,310$ \\
\hline Bovine meat & $-71,991,573$ & $183,404,312$ & $-68,048,175$ & $251,452,487$ & $6,573,363$ & $6,901,226$ & 13 & $6,901,213$ \\
\hline Sheep meat & $-397,725$ & $11,766,124$ & $-3,466,166$ & $15,232,290$ & 19,031 & $44,515,377$ & $-22,523$ & $44,537,901$ \\
\hline Pig meat & $7,844,226$ & $30,275,794$ & $-484,241$ & $30,760,036$ & 198,314 & 943,427 & $-4,004$ & 947,431 \\
\hline Poultry & $15,638,802$ & $141,658,925$ & $-730,112$ & $142,389,038$ & 105,515 & $13,757,465$ & $-75,473$ & $13,832,938$ \\
\hline Milk, conc. & $-12,218,767$ & $1,493,488$ & $-7,404,752$ & $8,898,239$ & $2,420,797$ & $1,231,944$ & 109,382 & $1,122,562$ \\
\hline Butter & $-331,593$ & $2,811,537$ & $-3,727,579$ & $6,539,115$ & $3,851,955$ & $115,608,739$ & $-5,177,498$ & $120,786,237$ \\
\hline Cheese & $-1,949,018$ & 393,097 & $-6,079,908$ & $6,473,004$ & $-15,711$ & 35,973 & 26,067 & 9,905 \\
\hline Wheat & $-43,853,537$ & 19,387 & $9,572,257$ & $-9,552,870$ & $20,446,870$ & $245,186,133$ & $-372,712$ & $245,558,845$ \\
\hline Rice & $-1,640,443$ & 37,313 & $-4,443,341$ & $4,480,654$ & $5,046,761$ & $47,995,105$ & $-23,225$ & $48,018,330$ \\
\hline Barley & $-199,993$ & 29,610 & $4,431,565$ & $-4,401,955$ & $2,820,472$ & -274 & $13,220,619$ & $-13,220,893$ \\
\hline Maize & $-4,260,303$ & $9,167,542$ & $-13,389,848$ & $22,557,390$ & $4,201,964$ & 113,718 & $8,278,251$ & $-8,164,534$ \\
\hline Sorghum & 160,579 & -271 & $2,071,729$ & $-2,072,001$ & $3,774,336$ & 730 & $8,081,697$ & $-8,080,966$ \\
\hline Pulses & $-68,459$ & 233 & $-776,344$ & 776,577 & $-2,128,273$ & 98,824 & $-2,993,392$ & $3,092,215$ \\
\hline Tomatoes & $-2,604,704$ & $19,804,174$ & $-19,919,440$ & $39,723,614$ & 419,566 & $102,244,137$ & $-210,822$ & $102,454,959$ \\
\hline Roots \& tubers & $-305,988$ & 18,309 & $-1,444,491$ & $1,462,800$ & 12,743 & $1,637,417$ & $-219,135$ & $1,856,552$ \\
\hline Apples & $-4,289,343$ & $1,078,486$ & $-14,694,373$ & $15,772,859$ & $-3,637,873$ & $13,293,034$ & $-10,636,625$ & $23,929,659$ \\
\hline Citrus fruits & $13,911,201$ & $217,402,310$ & $-1,340,722$ & $218,743,032$ & $-212,810$ & $44,027,520$ & $-1,803,390$ & $45,830,910$ \\
\hline Bananas & 432,018 & $23,965,774$ & $-5,629$ & $23,971,403$ & 0 & 0 & 0 & 0 \\
\hline $\begin{array}{l}\text { Other tropical } \\
\text { fruits }\end{array}$ & 172,585 & $16,224,421$ & $-3,625,120$ & $19,849,541$ & $-15,547,299$ & 409,922 & $-50,779,117$ & $51,189,039$ \\
\hline Sugar, raw & 707,868 & $119,303,734$ & $-414,095$ & $119,717,830$ & $3,250,450$ & $544,234,975$ & $-9,121$ & $544,244,096$ \\
\hline Sugar, refined & $64,271,834$ & $273,532,985$ & $-5,939$ & $273,538,924$ & $-4,242,257$ & $131,186,849$ & $-8,532,565$ & $139,719,414$ \\
\hline Coffee, green & 0 & 0 & 0 & 0 & $-482,331$ & $-891,126$ & 305,662 & $-1,196,788$ \\
\hline Coffee, proc. & 751,147 & $4,956,997$ & $-1,504,905$ & $6,461,902$ & $-1,144,235$ & 778,672 & $-2,480,544$ & $3,259,216$ \\
\hline Cocoa beans & $-1,824$ & $-4,098$ & $-168,832$ & 164,733 & $-1,244$ & -258 & $-8,640$ & 8,382 \\
\hline Cocoa, proc. & $1,590,232$ & $3,506,328$ & $-2,062,080$ & $5,568,408$ & $-62,354$ & 127,943 & 5,618 & 122,325 \\
\hline Tea & $-3,816$ & 12,387 & $-51,753$ & 64,140 & $-121,168$ & 36,552 & $-180,589$ & 217,141 \\
\hline Tobacco leaves & $4,321,398$ & $5,877,412$ & $-1,565,729$ & $7,443,141$ & 357,677 & $3,224,969$ & $-2,103,123$ & $5,328,092$ \\
\hline Hides \& skins & $6,076,333$ & $63,891,170$ & $-4,029,221$ & $67,920,392$ & $-4,871,078$ & 140,158 & $-761,637$ & 901,795 \\
\hline Oilseeds, temp. & $18,676,063$ & $30,522,422$ & $-28,872,010$ & $59,394,432$ & $1,032,645$ & $20,254,150$ & $-772,436$ & $21,026,586$ \\
\hline Oilseeds, trop. & 252,574 & $-8,746$ & $2,568,054$ & $-2,576,800$ & $-83,919$ & 445,394 & $-208,239$ & 653,633 \\
\hline Rubber & 0 & 0 & 0 & 0 & 0 & 0 & 0 & 0 \\
\hline Cotton & 598 & 2,946 & $-3,229$ & 6,176 & $-9,988$ & 475 & $-22,240$ & 22,716 \\
\hline Vegetable oils & $1,929,683$ & $2,660,948$ & $-1,782,830$ & $4,443,777$ & $-17,593,480$ & 414,691 & $-7,035,524$ & $7,450,215$ \\
\hline Total & $-7,435,321$ & $1,176,141,133$ & $-178,631,935$ & $1,354,773,068$ & $-655,530$ & $1,337,953,767$ & $-81,551,667$ & $\mathbf{1 , 4 1 9 , 5 0 5 , 4 3 4}$ \\
\hline
\end{tabular}

Notes: $\mathrm{TW}=$ total welfare; $\mathrm{XR}=$ export revenue; $\mathrm{MC}=$ import cost; $\mathrm{TB}=$ trade balance.

Source: Authors' estimated 